\title{
Following the pest outbreak: preliminary findings on the landscape effect on Dasineura oleae and its parasitoids in central Italy
}

\author{
Malayka Samantha Picchi ${ }^{(1)} \cdot$ Elena Tondini • \\ Nicola Albertarelli • Gaia Monteforti · \\ Ruggero Petacchi ${ }^{\circ}$
}

Received: 9 September 2020 / Accepted: 30 June 2021 / Published online: 28 September 2021

(C) The Author(s) 2022, corrected publication 2022

\begin{abstract}
Dasineura oleae (Angelini, 1831) (Diptera: Cecidomyiidae), the olive leaf gall midge, is a pest of olive crops that was not problematic in Italy until 2016 when a massive infestation of this pest was reported in a small region in central Italy. We identified infested olive orchards using farmers' reports and quantified the pest infestation level and parasitism rate in each field. We also explored the effect of the landscape on both the pest and parasitoids using the abundance of olive crops and semi-natural habitats and the Shannon index, estimated at four different scales $(250 \mathrm{~m}, 500 \mathrm{~m}, 750 \mathrm{~m}$ and $1000 \mathrm{~m}$ buffers around the sampling points). The results showed
\end{abstract}

Supplementary Information The online version contains supplementary material available at https://doi. org/10.1007/s12600-021-00962-4.

M. S. Picchi $(\bowtie) \cdot$ E. Tondini · G. Monteforti · R. Petacchi Biolabs, Institute of Life Science, Scuola Superiore Sant'Anna, Via Alamanni 22, San Giuliano Terme, 56127 Pisa, Italy

e-mail: m.picchi@santannapisa.it

E. Tondini

e-mail: elena.tondini@live.it

G. Monteforti

e-mail: g.monteforti@santannapisa.it

R. Petacchi

e-mail: r.petacchi@santannapisa.it

N. Albertarelli

Via canaletto16, Castelnuovo Magra, 19033, La Spezia, Italy a small-scale effect on the parasitism rate and a large-scale effect on leaf infestation mediated by the Shannon Index. Moreover, some preliminary results showed that the parasitism rate was high in sites where plants associated with $D$. oleae parasitoids were present in the adjacent semi-natural habitat. Further studies are needed to validate our findings on the effect of landscape and vegetation on the natural enemies of D. oleae in order to develop new suppression strategies.

Keywords Olive leaf gall midge $\cdot$ Platygaster demades $\cdot$ Semi-natural habitat $\cdot$ Erica sp.,conservation biological control

\section{Introduction}

Dasineura oleae (Angelini, 1831) (Diptera: Cecidomyiidae), commonly known as the olive leaf gall midge, damages to young leaves and flower buds (Barnes, 1948), however in several Mediterranean countries, it has always been considered as a minor pest of the olive tree (Olea europaea L.). The characteristics of this pest have thus never been extensively investigated and the literature on this topic is scarce. In Italy, this pest was not problematic until 2016, when several outbreaks were officially registered (Picchi et al., 2017).

In the following years, the infestation aspread unevenly, in the southern part of Tuscany (central 
Italy), particularly throughout the province of Grosseto (Petacchi et al., 2019; Picchi et al., 2017; Tondini \& Petacchi, 2019).

Through field observations, farmers and technicians reported that the pest is abundant in the countryside. Outbreaks have recently become common in the Mediterranean basin, leading to an increase in olive leaf gall midge case studies (Doğanlar et al., 2011; Batta, 2019; Batta \& Doganlar, 2020). However, apart from these studies, there is a little knowledge about D.oleae and there are no studies on the effect of this phytophagous insect on the olive yield.

On the other hand, results of Caselli et al. (2020) suggested that the pest may alter leaf morphology and influence some physiological activities of olive leaves related to photosynthesis performance. Other recent studies have explored the life cycle and the parasitoid complex of D. oleae.

The pest develops two generations every year: one in spring and one in autumn according to the favourable climatic conditions of coastal zones and spends the summer period as a second instar larva. During this period, some parasitoids may develop at the expense of the pest.

The natural enemies of $D$. oleae in Italy consist of four species of koinobiont endoparasitoids (Tondini \& Petacchi, 2019). Two species of parasitoids belong to the family of Pteromalidae (Mesopolobus aspilus (Walker, 1835) and Mesopolobus mediterraneus (Mayr, 1903)), whereas the other two are Platygastridae wasps (Platygaster demades Walker 1835 and Platygaster oleae Szelenyi 1940). Only P. oleae is a specific parasitoid of D. oleae. Both Pteromalidae and Platygastridae include species that are effective control agents of many Cecidomyiidae species. (He \& Wang, 2011; Roubos \& Liburd, 2013; Sampson et al., 2002).

A survey of the current pest status and natural enemies may provide useful information for defining guidelines for Integrated Pest Management (IPM) (Barzman et al., 2015). In addition,pest trends and its natural enemies can provide broader information on the effect of crop-pest synchrony in the long term (Haynes et al., 2014) as well as the dispersal probability, temperature tolerance and preference of its parasitoids (Chaianunporn \& Hovestadt, 2015) and the effect of the composition and configuration of the landscape. In fact, pest outbreaks and pest control by natural enemies have very strong links to landscape patterns and are not just dependent on local conditions in the field (With et al., 2002).

The arthropods of cultivated fields are influenced by the surroundings habitats. Favorable local and landscape conditions with specific ecological traits can enhance predators and parasitoids and can lead to higher rates of pest suppression (Bengtsson et al., 2005; Bianchi et al., 2006; Haan et al., 2020; Happe et al., 2019; Tschumi et al., 2016). Usually, a high proportion of semi-natural habitats (hereafter "SNH") benefit natural enemies (Chaplin-Kramer \& Kremen, 2012 but see Tscharntke et al., 2005; Hawro et al., 2015) and an increase in the complexity of the landscape corresponds to a greater parasitism in the crop (Cronin \& Reeve, 2005) however the biological control could also depend on the taxon-specific mobility and dispersal capacity of pests and natural enemies (Gallé et al., 2019; Happe et al., 2019; Schweiger et al., 2005).

Indeed, SNH provides natural enemies with resources such as alternative hosts or/and overwintering shelters. D. oleae parasitoids, except $P$. oleae, are oligophagous or polyphagous. It is therefore likely that vegetation adjacent to olive orchards hosts several plant species associated with alternative hosts (hereafter "associated plants"). Also, M. mediterraneus and M. aspilus are polyphagous parasitoids and hyperparasitoid that attack numerous Cecidomyiidae (Askew et al., 2001; Del Bene \& Landi, 1993; Doğanlar, 2011; Graham, 1969) and several species belonging to different insect orders (Askew et al., 2013; Gomez et al., 2006; Herting \& Simmonds, 1973, 1975; Öncüer, 1991; Vidal, 1997; Viggiani, 1967).

These hosts are associated with plants such as Quercus spp. and Clematis vitalba (Askew et al., 2013; Gomez et al., 2006; Xiao et al., 2016). Platygaster demades is an oligophagous parasitoid that attacks D. oleae, Dasineura pyri (Bouché, 1847), Dasineura mali (Kieffer, 1904) and Wachtliella ericina (Low, 1885), associated with O.europaea, Malus domestica (Suckow) Borkh (1803), Pyrus communis subsp. pyraster (L.) Ehrh. and Erica spp., respectively.

In this paper, we estimated the infestation level of $D$. oleae by evaluating the number of galls per infested leaf as an indicator of the intensity of the pest attack and the leaf infestation rate as the indicator of the extent of the infestation and it was used to assess the effect of the landscape. We also, we calculated the 
effect of parasitoids, based on the parasitism rate. We then provided farmers with management guidelines based on the number of galls per infested leaf in combination with the parasitism rate.

We carry out a preliminary investigation of the effects of landscape characteristics on the leaf infestation rate and parasitism by measuring the landscape composition (i.e. the proportion of olive orchards and proportion of $\mathrm{SNH}$ ) and diversity (i.e. Shannon index "SH", richness of the different land cover classes in the landscape) at four spatial scales $(250 \mathrm{~m}, 500 \mathrm{~m}$, $750 \mathrm{~m}$, and $1000 \mathrm{~m}$ radius) around the sampling sites.

Finally, we obtained preliminary data on the effect of the associated plants on the biological control of D. oleae.

\section{Materials and methods}

The study area

The survey was carried out in the province of Grosseto, a coastal area of southern Tuscany (central Italy). The area covers $5000 \mathrm{~km}^{2}$ and $25 \%$ of its territory is defined as "Utilised Agricultural Area" (UUA) (Regione Toscana, 2012). Olive orchards occupy $14,5 \%$ of the land, which are generally small fields (Maselli et al., 2012). The province of Grosseto produces $20 \%$ of the olive oil and hosts $19 \%$ Tuscany's oil mills (ISMEA, 2018).

The climate is typically Mediterranean with dry and hot summers ("Csa" type according to the Köppen-Geiger classification (Peel et al., 2007)), average annual rainfall of $730 \mathrm{~mm} /$ year and the lowest rainfall in in July $(5 \mathrm{~mm})$. February is the coldest month with a mean minimum of $0^{\circ} \mathrm{C}$ and July is the hottest with a mean maximum of $32^{\circ} \mathrm{C}$ (Vallebona et al., 2015).

Grosseto is the driest and warmest area of Tuscany, with long periods of summer drought and it is therefore more suitable for olive growers rather than other crops, since olive have physiological mechanisms that confer resistance to drought stress (Sofo et al., 2008).

\section{Monitoring of Dasineura oleae and its parasitoids}

The sampling points were olive orchards selected from a database of local reports of $D$. oleae infested sites and considering the olive land use. Initially, we collected information on infested fields in previous years from providers of extension services and consortiums in the province (OLMA, Terre dell'Etruria, Consorzio Agrario del Tirreno). Their data came from visual inspection of $D$. oleae infestations and they also provided GPS coordinates and an approximate estimation of the level of infestation. We, then calculated the size of the area dedicated to olive orchards using the "Utilised Agricultural Area" (UUA) value for each municipality. Finally, we drew up a list of 24 representatives for infested olive orchards for our study (Fig. 1A).

Many farmers use dimethoate against the olive fruit fly (Bactrocera oleae, Rossi 1970; Diptera Tephritidae) in the summer however, during the period of sampling and in previous years, no treatments were applied against the olive leaf midge.

In the proximity of the middle of each field, we performed a transect starting from the third row of the edge toward the centre of the field to minimize the edge effect and spillover from adjacent fields. We sampled six trees, choosing one tree every two, within the transect.

Four sprigs were collected from each tree, one from each cardinal direction at circa $1.5 \mathrm{~m}$ height consisting of the eight apical nodes of the branch, in order to collect the last growth of the plants and therefore, the last generation of $D$. oleae.

In the laboratory, we counted the number of leaves, the number of infested leaves and the number of galls in each sample (branch). For each olive orchards, we calculated the percentage of infested leaves ("leaf infestation rate"), the ratio between the number of galls and the number of infested leaves ("galls per infested leaf"). Then, samples of galls were dissected under the stereomicroscope (Tondini \& Petacchi, 2019). The number of galls dissected per sample was randomly chosen in infested leaves and ranged from a minimum of one gall (if the number of galls did not reach 10) to a rounded figure of $10 \%$ of the galls in leaves of each sprig collected. The parasitism rate was calculated as the relative abundance of parasitoids on the number of galls inspected (Tondini \& Petacchi, 2019).

Olive orchards were visited between 26 March and 3 April 2019, which was the last period available before the emergence of pest and parasitoids. During this period, $D$. oleae develops into the third instar 

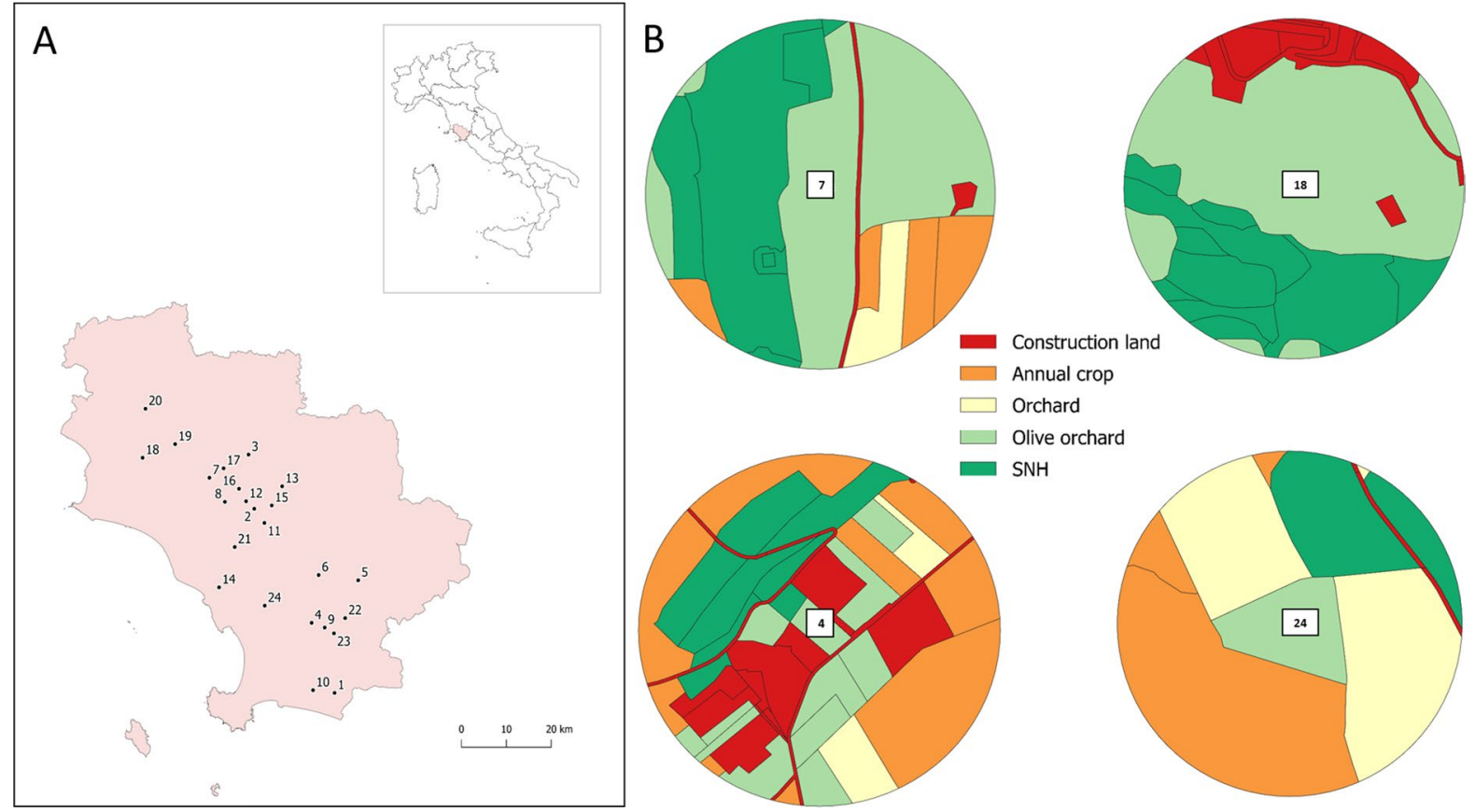

Fig.1 A Map of the 24 olive orchards considering during the survey on Dasineura oleae. The olive orchards were located in the province of Grosseto (central Italy). B Landscape patterns

stage and parasitisation become evident (Tondini \& Petacchi, 2019).

Landscape metrics and vegetation sampling

The landscape analysis was performed using QGis 3.8.2 Zanzibar (QGIS Development Team, 2019). We evaluated the land-use of the 24 fields in four concentric buffers with radii of $1000 \mathrm{~m}, 750 \mathrm{~m} 500 \mathrm{~m}$ and $250 \mathrm{~m}$ buffer, nested around each olive orchard. The land-use classes were obtained from the Geoscopio WebGIS Service of Tuscany region (Regione Toscana, 2020). The types of land-use belong to five classes: excluding olive orchards and $\mathrm{SNH}$, construction land, annual crop and other types of orchards were considered.

The abundance of olive orchards and SNH land use were calculated for each buffer and were used as estimators of landscape composition. In addition, we evaluated the spatial diversity of each buffer through the SH index. This index considers the proportional abundance of each habitat type of focal fields (4, 718 and 24), at $250 \mathrm{~m}$ buffer, in which the botanical composition in the adjacent $\mathrm{SNH}$ was evaluated

with the highest value for the smallest amount of land-use dominance (McGarigal et al., 2012).

We collected preliminary data on plant assemblages in the SNH surrounding the olive orchards. To do this, we chose four fields to represent the combination of two levels of abundance of SNH in the $250 \mathrm{~m}$ buffer (high and low) and two levels of parasitism (high and low).

The landscape models in $250 \mathrm{~m}$ buffers around these fields are shown in Fig. 1B. The spontaneous vegetation in $\mathrm{SNH}$ was sampled with three transects of $100 \mathrm{~m}$ at five different distances $(0 \mathrm{~m}, 25 \mathrm{~m}, 50 \mathrm{~m}, 75 \mathrm{~m}, 100 \mathrm{~m})$, starting from the edge with olive orchard towards the field. In each site, the transects were perpendicular to the olive orchards and parallel between them. The abundance of both associated plants and "non-associated plants" (i.e. plant species not associated with alternative hosts of parasitoids) was evaluated by visually assessing the percentage cover of each species in a $250 \mathrm{~m}$ buffer around each sampling point. 
Statistical analysis

All the analyses were performed with $\mathrm{R}$ software ( $\mathrm{R}$ Development Core Team, 2016). First, we ensured that $1000 \mathrm{~m}$ buffers did not overlap more than $10 \%$ in order to guarantee statistical independence (Steffan-Dewenter, 2002). We checked the collinearity among landscape variables through the function "pair.panels" (psych package; Revelle, 2020).

The effect of landscape factors (olive orchards abundance, SNH abundance and SH index) on the leaf infestation and parasitism rate were estimated through Generalized Linear Models using a binomial distribution (Zuur et al., 2009). Since overdispersion was detected, we corrected the standard errors using a quasi-binomial model for each scale. The interaction between the abundance of olive orchards, $\mathrm{SNH}$ and $\mathrm{SH}$ index was evaluated in the models. The minimum adequate model was selected by a backward selection using the "drop" function in the package "stats" (Chambers, 1992; SM1) Significant variables according to GLMs were also tested by exploring landscape traits of sites by a Kmeans partitioning. Which was carried out using the values of the landscape indices described above.

The optimal number of clusters was assessed using the Elbow method based on the sum of the square for each cluster (Zhang et al., 2016) and the characteristics of each cluster were evaluated graphically (package ggiraphExtra: Moon, 2018).

We estimated differences in the parasitism rate among clustered sampling sites using Generalized Linear Models. The parasitism rate was used as the response variable and landscape factors the explanatory variables. A binomial distribution of the data was assumed.

The model was tested against a null model and $\chi 2$ and $p$-values were obtained by likelihood tests.

Estimated marginal means and standard errors were obtained with the function "emmeans" (emmeans package: Lenth, 2020) and post-hoc Tukey tests were performed with "multcomp" (Hothorn et al., 2008).

To visualize the association between plant species type ("associated" or "non-associated") and sampling sites we calculated the average cover of each plant species for each sampling site (sites 4, 7, 18 and 24). Then we performed a correspondence analysis (CA) using the packages "FactoMineR"
(Lê et al., 2008) and "factoextra" (Kassambara \& Mund, 2019).

In the CA, O.europaea was not considered because it is not attacked by other insect species that are potential hosts for parasitoids, apart from D. oleae.

\section{Results}

Infestation and parasitism rates

We found that the mean number of infested leaves out of the total number of leaves sampled was $23 \%$, with the highest value being $71 \%$. Only 3 out of the 24 olive orchards had more than $50 \%$ of leaves infested. The average number of galls per infested leaf was 1.77 and the infestation range varied from 1 to 3.24 galls per infested leaf. The average parasitism value was $15.8 \%$ with the parasitism rate ranging between $0.0 \%$ and $43.75 \%$. Parasitoids were absent in samples from three olive orchards. The results of each olive orchard are reported in Table 1.

The landscape effect

GLMs showed significant effects at $250 \mathrm{~m}, 750 \mathrm{~m}$ and $1000 \mathrm{~m}$ buffer, as reported in Fig. 2. At the $250 \mathrm{~m}$ scale, the parasitism rate increased as the $\mathrm{SH}$ index increased (Fig. 2A). This positive effect was then explored by multivariate analysis. The cluster analysis showed four distinct clusters (Fig. 3A and B), characterized by: high landscape diversity; low landscape diversity with a high proportion of olive orchards and SNH; high olive orchard abundance and a cluster that showed both a low abundance of olive orchards and $\mathrm{SNH}$, and low landscape diversity ("Mixed land-use").

GLM underlined a significant difference between clusters $(p=0,003)$. Using a post-hoc test, we then explored the differences between clusters (Fig. 3C) highlighting the positive effect of landscape diversity on the parasitism rate. No significant effect of the tested landscape variables was detected at the $500 \mathrm{~m}, 750 \mathrm{~m}$ and $1000 \mathrm{~m}$ buffers for the parasitism rate. On the other hand, the infestation rate showed a crossover interaction between the landscape variables at $250 \mathrm{~m}$, and a significant increase of infestation as the diversity increased in large buffers, at $750 \mathrm{~m}$ and $1000 \mathrm{~m}$ (Fig. 2B and C), however it 


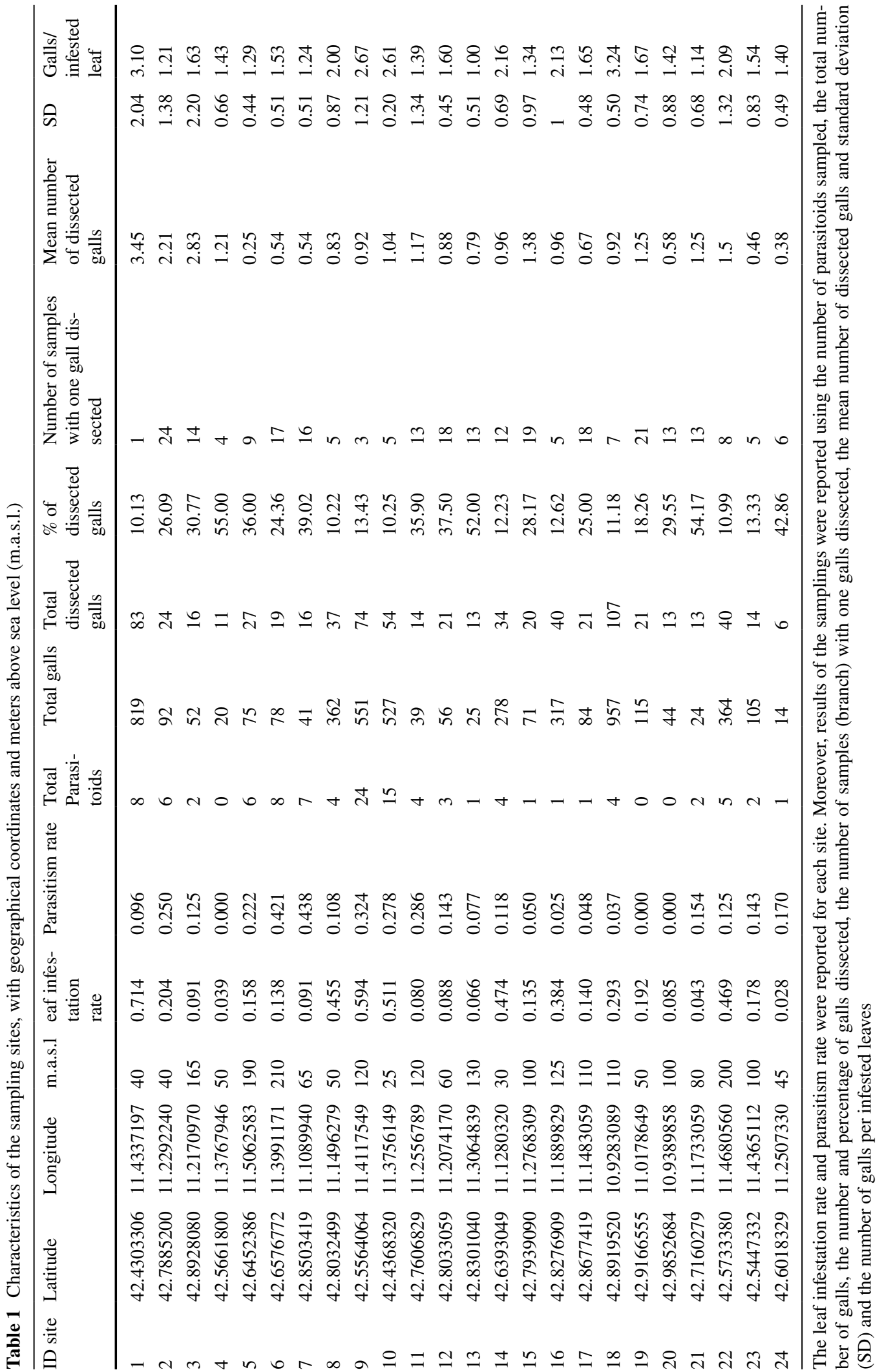



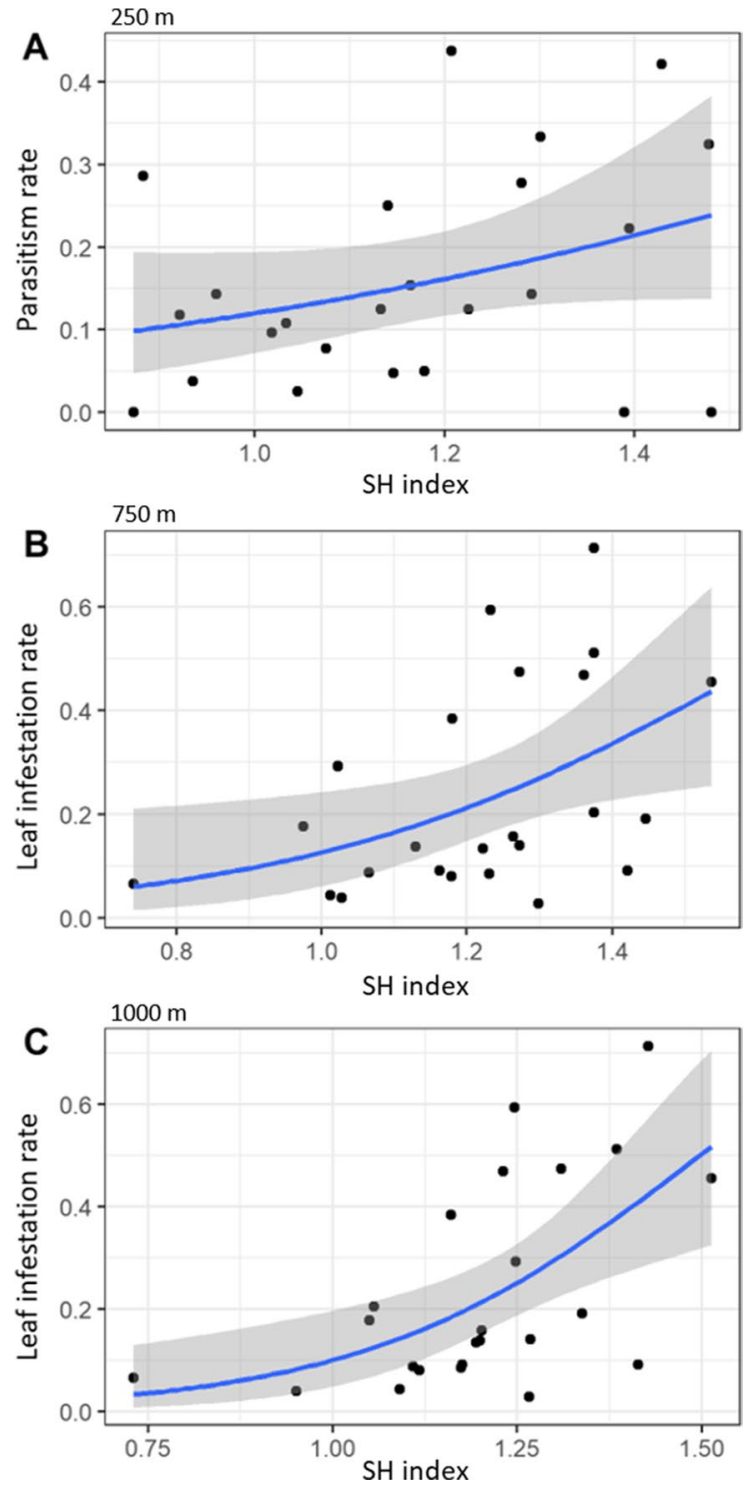

Fig. 2 Effect of Shannon landscape diversity index (SH), with confidence intervals of $95 \%$ on $\mathbf{A}$ the parasitism rate on D. oleae at the $250 \mathrm{~m}$ scale buffer $\left(\mathrm{F}_{1}=7.65, p\right.$ value $\left.=0.011\right)$ B the leaf infestation rate by $D$. oleae at the $750 \mathrm{~m}$ scale buffer $\left(\mathrm{F}_{1}=5.18, p\right.$ value $\left.=0.032\right)$ and $\mathbf{C}$ the leaf infestation rate by $D$. oleae at the $1000 \mathrm{~m}$ scale buffer $\left(\mathrm{F}_{1}=11.93, p\right.$ value $=0.002$ )

was not possible to explore the characteristics of the sites in more detail due to clustering problems.
There were not enough sites to divide olive fields according to the variables chosen.

The analysis of the vegetation profile

Fields were selected corresponding to four combinations of the $\mathrm{SNH}$ abundance and parasitism rate, respectively. Site 7 corresponds a high abundance of SNH (37.67\%) and high parasitism rate (43.75\%); site 18 to a high abundance of SNH (32.35\%) and low rate of parasitism (5\%), site 24 to low abundance of $\mathrm{SNH}$ $(16.58 \%)$ and high rate of parasitism $(16.67 \%)$ and site 4 to a low abundance of SNH (17.65\%) and low rate of parasitism $(0.0 \%)$.

Analyses of the vegetational composition revealed the presence of 28 plant species in the adjacent vegetation, of which seven species were associated with alternative hosts of the parasitoids complex of D. oleae (Table 2).

Quercus sp. was the only species found in site 18 (high SNH-low parasitism rate), while site 4 (low SNHlow parasitism rate) hosted Quercus sp. and also $C$. vitalba.

Regardless of the composition of the landscape, the other two fields with a high parasitism rate hosted three and five associated plant species, respectively. Besides olive and oak trees, Erica sp. and P.communis subsp. pyraster were in the surrounding of the two fields, which are both plants associated with alternative hosts of $P$. demades.

Considering the associated plant cover, sites with a high parasitism rate had a high cover of associated species in the adjoining vegetation, while sites with low parasitism rate had a low cover of associated plant species. Notably, site 7 had a parasitism rate of $44 \%$ and hosted in $75.3 \%$ of the Erica sp.

The results of the correspondence analysis (Fig. 4) show that dimensions 1 and 2 explain $85.96 \%$ of the total variance. Rubus ulmifolius Schott, Erica sp. and Quercus sp. contributed the most to the definition of dimensions 1 and 2. Considering the associated species, site 7 was associated with Erica sp. and Quercus suber L. The presence and abundance of Quercus cerris L., Pyrus communis subsp. pyraster and Quercus sp. were related to site 24 . Site 4 was associated with $C$. vitalba L. and Quercus sp. and site 18 with the presence of Quercus ilex L. subsp. ilex. 
A

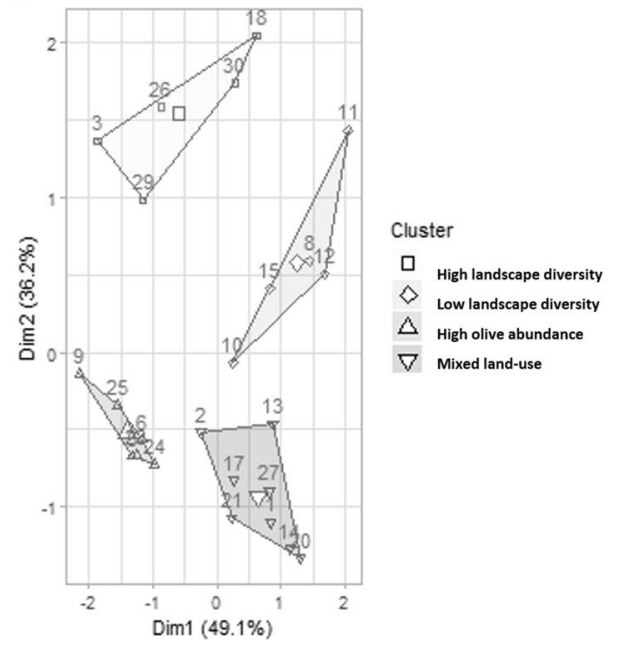

B

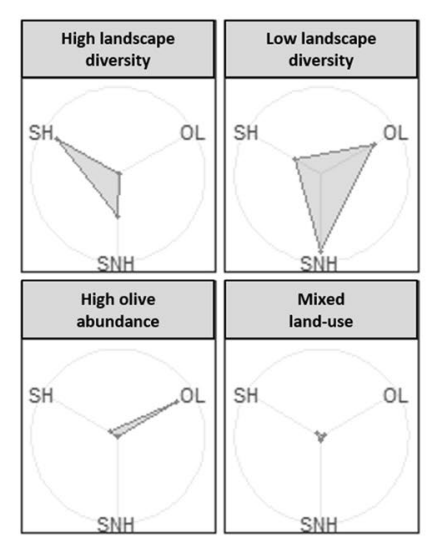

C

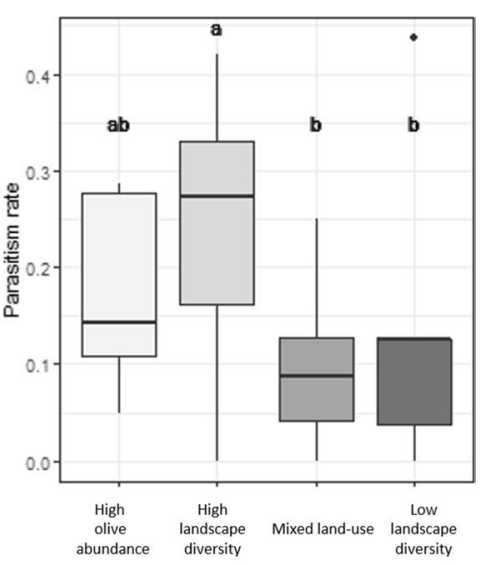

Fig. 3 The cluster analysis of the parasitism rate on D.oleae in the $250 \mathrm{~m}$ scale buffer: A the olive fields as clustered by environmental variables; $\mathbf{B}$ the structure of each cluster using environmental variables: abundance of olive (OL) abundance

\section{Discussion}

Dasineura oleae always used to be considered a minor pest in olive orchards. Consequently, the influence of biotic and abiotic factors on this pest and its natural enemies as well as the effects on plant physiology and yield have never been thoroughly investigated. In this study, we assessed the infestation and the parasitism rate in 24 olive orchards in an outbreak area in Italy. Our aim was to understand the significance of several environmental factors by analysing preliminary findings of the effect of landscape on both leaf infestation by the olive leaf gall midge and parasitism rate. In addition, we investigated the importance of the plant assemblages in the surroundings $\mathrm{SNH}$ in terms of improving the biocontrol of D.oleae.

The average leaf infestation rate was lower than had been estimated in 2017 in the same area (Tondini \& Petacchi, 2019), although some orchards had a severe infestation with more than $50 \%$ of infested leaves. In Turkey, Doğanlar et al. (2011) reported an average leaf infestation rate of $15 \%$ and the average parasitism rate of $66.2 \%$ consisted mostly of E.urozonus. On the other hand in Palestine, they found an average rate of $36.4 \%$ of leaf infestation and an average parasitism rate of $35.6 \%$ with the dominance of P.oleae (Batta \& Doganlar, 2020). These of semi-natural habitat ( $\mathrm{SNH}$ ) and Shannon landscape diversity index $(\mathrm{SH})$; $\mathbf{C}$ The boxplot of the parasitism rate for each cluster, considering the average value. In addition, the Tukey posthoc results are reported

authors suggest that differences could be linked to the elevation of the olive orchards considered in their study.

Our preliminary findings showed a landscape effect mediated by the diversity of the land cover. The parasitism rate was significantly influenced by the $\mathrm{SH}$ index only at the smallest scale which was confirmed by the multivariate analysis and a post-hoc approach. These findings support the hypothesis that parasitoids, with their limited body size, do not travel far (Kruess \& Tscharntke, 1994, 2000; Ritchie \& Olff, 1999).

In addition, we observed that the parasitism is also high in clusters characterized by a high abundance of olive orchards, where parasitoids may find the olive leaf gall midge during the season.

Landscape diversity is the main driver of the effectiveness of natural enemies because diverse habitats support different natural enemy assemblages (Bianchi et al., 2006; Redlich et al., 2018). In fact, this could lead to an increasing rate of pest suppression (Greenop et al., 2018; Griffin et al., 2013; Letourneau et al., 2009). Different habitat types provide different resources and, in the case of parasitoids with multiple hosts living on different plant species, food availability can be a key factor in the population dynamics of a parasitoid-host system (Wackers, 2002). 
Table 2 List of plant species sampled in sites 4,7,18 and 24 during the survey on Dasineura oleae

\begin{tabular}{|c|c|c|c|c|c|c|c|c|c|}
\hline \multirow[t]{2}{*}{ Families } & \multirow[t]{2}{*}{ Plants } & \multirow{2}{*}{$\begin{array}{l}\text { Alternative } \\
\text { host plants } \\
\text { species }\end{array}$} & \multirow[t]{2}{*}{ Parasitoids } & \multirow[b]{2}{*}{ ID 4} & \multirow[b]{2}{*}{ ID 7} & \multirow[b]{2}{*}{ ID 18} & \multirow[b]{2}{*}{ ID 24} & \multirow[b]{2}{*}{ Notes } & \multirow[t]{2}{*}{ CA code } \\
\hline & & & & & & & & & \\
\hline Anacardiaceae & $\begin{array}{l}\text { Pistacia lentiscus } \\
\mathrm{L}\end{array}$ & & & & & & & & Pi_len \\
\hline \multirow[t]{2}{*}{ Asparagaceae } & $\begin{array}{l}\text { Asparagus acuti- } \\
\text { folius } \mathrm{L}\end{array}$ & & & & & & & Naturalized & As_acu \\
\hline & $\begin{array}{l}\text { Ruscus aculea- } \\
\quad \text { tus } \mathrm{L}\end{array}$ & & & & & & & & $\mathrm{Ru} \_\mathrm{acu}$ \\
\hline Cistaceae & Cistus sp. & & & & & & & & Ci_sp \\
\hline \multirow[t]{2}{*}{ Ericaceae } & Arbutus unedo & & & & & & & & Ar_une \\
\hline & Erica sp. & $X$ & $\begin{array}{l}\text { Platygaster } \\
\quad \text { demades } \\
\quad \text { (Walker, 1835) }\end{array}$ & & $\mathrm{x}$ & & $\mathrm{x}$ & & Er_sp \\
\hline \multirow[t]{3}{*}{ Fabaceae } & $\begin{array}{l}\text { Robinia pseudoa- } \\
\quad \text { cacia } \mathrm{L}\end{array}$ & & & & & & & Invasive & Ro_pse \\
\hline & $\begin{array}{l}\text { Spartium jun- } \\
\text { ceum } \mathrm{L}\end{array}$ & & & & & & & Naturalized & $\mathrm{Sp \_ jun}$ \\
\hline & $\begin{array}{l}\text { Cytisus spinosus } \\
\text { (L.) }\end{array}$ & & & & & & & & Cy_spi \\
\hline \multirow[t]{4}{*}{ Fagaceae } & Quercus cerris L & $X$ & $\begin{array}{l}\text { Mesopolobus } \\
\text { mediterraneus } \\
\text { (Mayr, 1903) }\end{array}$ & & & & $\mathrm{x}$ & & Qu_cer \\
\hline & $\begin{array}{l}\text { Quercus ilex } L . \\
\text { subsp. ilex }\end{array}$ & $\mathrm{X}$ & $\begin{array}{l}\text { Mesopolobus } \\
\text { mediterraneus } \\
\text { (Mayr, 1903) }\end{array}$ & & & & $\mathrm{x}$ & & Qu_ile \\
\hline & Quercus sp. & $X$ & $\begin{array}{l}\text { Mesopolobus } \\
\text { mediterraneus } \\
\text { (Mayr, 1903) }\end{array}$ & $\mathrm{x}$ & & $\mathrm{x}$ & $\mathrm{x}$ & & Qu_sp \\
\hline & Quercus suber L & $X$ & $\begin{array}{l}\text { Mesopolobus } \\
\text { mediterraneus } \\
\text { (Mayr, 1903) }\end{array}$ & & $\mathrm{x}$ & & & Alien & Qu_sub \\
\hline Lamiaceae & $\begin{array}{l}\text { Lavandula stoe- } \\
\text { chas L. subsp. } \\
\text { stoechas }\end{array}$ & & & & & & & & La_sto \\
\hline Lauraceae & Laurus nobilis L & & & & & & & Naturalized & La_nob \\
\hline Myrtaceae & $\begin{array}{l}\text { Myrtus commu- } \\
\text { nis } \mathrm{L}\end{array}$ & & & & & & & & My_com \\
\hline \multirow[t]{2}{*}{ Oleaceae } & $\begin{array}{l}\text { Fraxinus ornus } L . \\
\text { subsp. ornus }\end{array}$ & & & & & & & & Fr_orn \\
\hline & Phillyrea sp. & & & & & & & & $\mathrm{Ph} \_s p$ \\
\hline Poaceae & Arundo donax $\mathrm{L}$ & & & & & & & Invasive & Ar_don \\
\hline Ranunculaceae & $\begin{array}{l}\text { Clematis vitalba } \\
\mathrm{L}\end{array}$ & $\mathrm{X}$ & $\begin{array}{l}\text { Mesopolobus } \\
\text { mediterraneus } \\
\text { (Mayr, 1903) }\end{array}$ & $\mathrm{x}$ & & & & & Cl_vit \\
\hline Rhamnaceae & $\begin{array}{l}\text { Paliurus spina- } \\
\text { christi Mill }\end{array}$ & & & & & & & Naturalized & Pa_spi \\
\hline
\end{tabular}


Table 2 (continued)

\begin{tabular}{|c|c|c|c|c|c|c|c|c|c|}
\hline \multirow[t]{2}{*}{ Families } & \multirow[t]{2}{*}{ Plants } & \multirow{2}{*}{$\begin{array}{l}\text { Alternative } \\
\text { host plants } \\
\text { species }\end{array}$} & \multirow[t]{2}{*}{ Parasitoids } & & & & & & \multirow[t]{2}{*}{ CA code } \\
\hline & & & & ID 4 & ID 7 & ID 18 & ID 24 & Notes & \\
\hline \multirow[t]{4}{*}{ Rosaceae } & $\begin{array}{l}\text { Crataegus } \\
\quad \text { monogyna Jacq }\end{array}$ & & & & & & & & Cr_mon \\
\hline & $\begin{array}{l}\text { Pyrus communis } \\
\text { subsp. pyraster } \\
\text { (L.) Ehrh }\end{array}$ & $X$ & $\begin{array}{l}\text { Platygaster } \\
\text { demades } \\
\text { (Walker, 1835) } \\
\text { Mesopolobus } \\
\text { mediterraneus } \\
\text { (Mayr, 1903) }\end{array}$ & & $\mathrm{x}$ & & $\mathrm{x}$ & & Py_pyr \\
\hline & Rosa canina $\mathrm{L}$ & & & & & & & & Ro_can \\
\hline & $\begin{array}{l}\text { Rubus ulmifolius } \\
\text { Schott }\end{array}$ & & & & & & & & Ru_ulm \\
\hline Santalaceae & Osyris alba $\mathrm{L}$ & & & & & & & & Os_alb \\
\hline Smilacaceae & Smilax aspera $\mathrm{L}$ & & & & & & & & Sm_asp \\
\hline Ulmaceae & Ulmus sp. & & & & & & & & Ulm_sp \\
\hline Viburnaceae & Sambucus sp. & & & & & & & & Sam_sp \\
\hline Total & $\underline{18}$ & $\underline{30}$ & 7 & & $\underline{\mathbf{2}}$ & $\underline{\mathbf{3}}$ & $\underline{1}$ & $\underline{\mathbf{5}}$ & \\
\hline$\%$ Olive orchards & & & & & $19.03 \%$ & $43.81 \%$ & $56.31 \%$ & $9.59 \%$ & \\
\hline$\% \mathrm{SNH}$ & & & & & $17.65 \%$ & $37.67 \%$ & $32.35 \%$ & $16.58 \%$ & \\
\hline Parasitism Rate & & & & & $0 \%$ & $43.75 \%$ & $5 \%$ & $16.67 \%$ & \\
\hline Host Plant Cover & & & & & $2.3 \%$ & $82.13 \%$ & $22.46 \%$ & $63.2 \%$ & \\
\hline $\begin{array}{l}\text { CoverPyrus com- } \\
\text { munis subsp. } \\
\text { pyraster }\end{array}$ & & & & & $0 \%$ & $0 \%$ & $0 \%$ & $1 \%$ & \\
\hline CoverErica sp. & & & & & $0 \%$ & $75.3 \%$ & $0 \%$ & $4.6 \%$ & \\
\hline
\end{tabular}

Species known to be plants associated with alternative hosts of parasitoids from the literature are cross-checked. Indeed, for each sampling sites we reported plants that were sampled in the $250 \mathrm{~m}$ buffer. There are also notes and codes associated with the CA (Fig. 4). Below the percentage of the abundance of olive and semi-natural habitats (SNH) with the parasitism rate and the cover of associated plants are reported. The percentage cover of Erica sp. and Pyrus communis subsp. pyraster was indicated as they are associated with alternative hosts of Platygaster demades

In addition, our preliminary results on the composition of adjacent vegetation suggested that, from the parasitoid perspective, the diversity of the landscape seems more relevant than the amount of SNH. The four fields consisted of different vegetation assemblages, as shown in the CA, and where Erica sp. was sampled. and, to a lesser extent P.communis subsp. pyraster, the parasitism rate was found to be high, regardless of the composition of the landscape. Erica sp. was present in both fields with a high abundance of parasitoids and where the parasitism rate reached $44 \%$ the highest cover of Erica sp. was found.

These plants are both attacked by alternative hosts of $P$. demades, such as Wachtliella ericina (Low, 1885), a gall-inducing insect of Ericaceae (Ghahari
\& Buhl, 2011; Skuhrava \& Skuravy, 1994) and Dasineura pyri (Bouchè, 1847), the pear leaf midge.

Tondini et al. (unpublished results) used Malaise traps to evaluate the species and the abundance of parasitoids of $D$. oleae in olive orchards in the same province. These authors highlighted that $P$. demades was the most abundant olive leaf gall midge parasitoid.

Although the data refers to a simple combination of a limited number of fields, we hypothesized that the presence of Erica sp. in the proximity of the olive field is essential to support the population of of $P$. demades hosted in Erica sp. in the adjoining vegetation, may quickly colonize olive orchards when the $D$. oleae population increases. 
Fig. 4 Correspondence analysis of the vegetation composition of focal olive orchards. Plants associated with alternative hosts of the parasitoids of Dasineura oleae are showed in red. The legend can be found in Table 2 "CA code" column

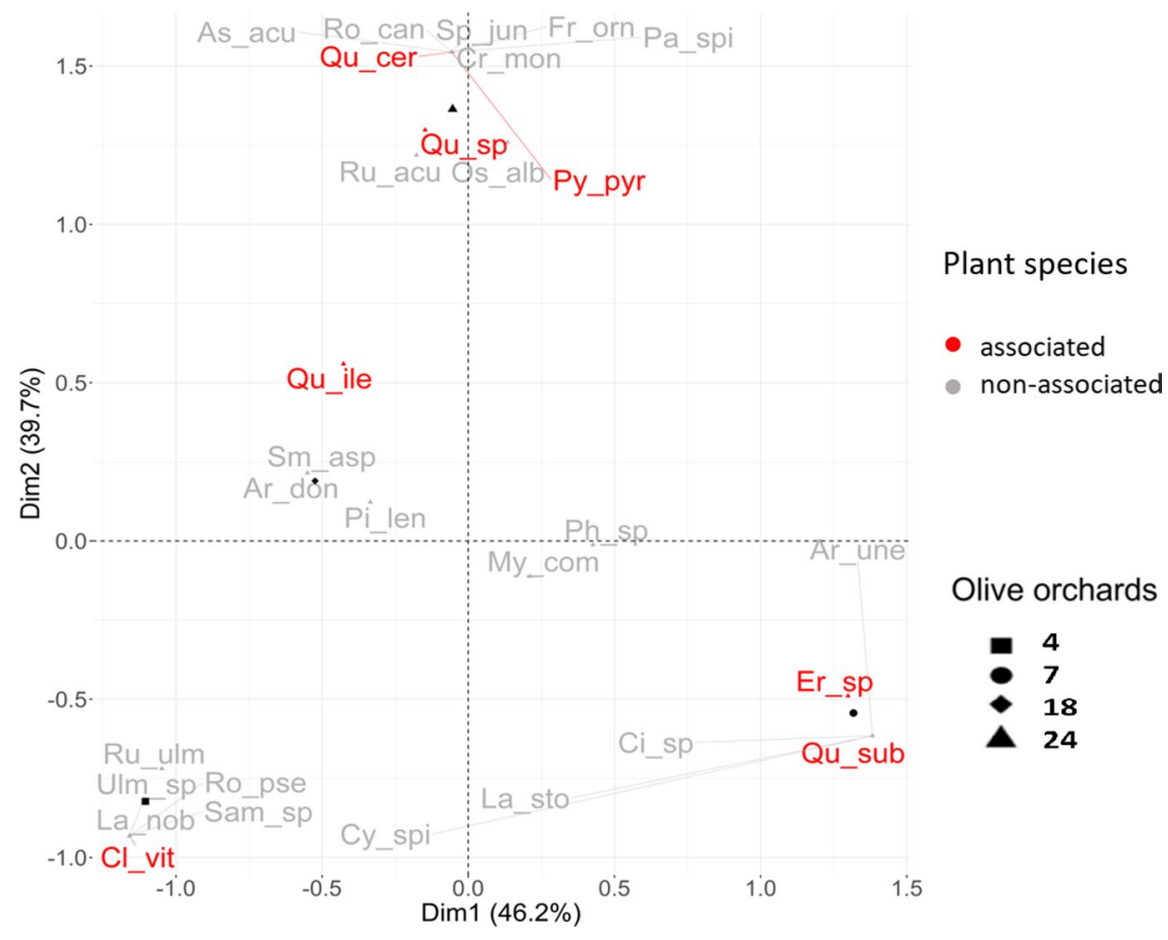

Parasitoids can also be able to find chemical cues to the host location. First, they use general cues emitted by different plant species in the host habitat and then intercept specific cues to accurately locate the host (Meiners, 2015, Silva \& Clarke, 2020). Different habitats with wild or cultivated species may therefore promote the abundance of parasitoids and affect their effectiveness on D. oleae galls.

Unexpectedly, a significant effect of the SNH abundance on the pest was not found in our study, despite it is usually being an important factor for pest control. The review made by Veres et al. (2013) highlighted that high proportions of semi-natural areas exhibited a low pest abundance in adjacent crop fields.

Usually, non-crop perennial habitats provide alternative resources that sustain the natural enemy assemblage. Further case studies would provide a more reliable conclusions regarding this issue.

At the $750 \mathrm{~m}$ and $1000 \mathrm{~m}$ buffer scale, the leaf infestation increased as the diversity of the landscape increased. We expected the leaf infestation to increase where olive orchards were most abundant since, to our knowledge, D. oleae has no alternative host plant and spends the entire life cycle in the crop. In addition, currently there is no specific pesticide formula against olive leaf gall midge. The relationship between olive orchards abundance and the pest should therefore have been positive. The availability of food resources is one of the major driver of many pests (Power, 1992). However, we found that land cover diversity supported a high level of olive leaf infestation. A complex landscape may favour not only natural enemies but also the pest aphid population as found in cereal crop by Thies et al. (2005), leading to an overall neutral effect of the landscape on the biological control.

Apart from the need for further data validation, other factors may help to explain this. One hypothesis is that due to an increase of the land diversity, the natural enemy population may steer other organisms, or rather become prey or hyperparasitized, thus less effective at large scale (Rosenheim, 1998). This situation then benefits the olive leaf gall midge.

Frere et al. (2007) call this situation "apparent mutualism": if predators become satiated by higher densities of one alternative prey species, then a second prey species may benefit from the presence of the first, and therefore the pest may benefit from the lack of spillover inside cultivated fields. Besides, by its complex structure, olive orchards may not be affected by spillover of functional diversity from the outside (Albertini et al., 2017; Picchi et al., 2016, 2019). 
We do not want to rule out other factors that could mask some important environmental variables, Further analysis over time and space is thus needed to understand better how the effect of the landscape depends on other abiotic factors such as temperature, rainfall, photoperiod or other variables related to the development of the olive tree, in addition to the role of complementary local scale variables that strictly depend on the traits of pest and of the natural enemies community. In fact, some land use variables may not completely capture the specific ecological prerequisites of such organisms (Aartsma et al., 2020).We also found a small-scale crossover effects on the infestation rate but not an overall effect of single variables. The role of the landscape on the olive leaf gall midge needs more investigation. Our preliminary results suggest that both pest leaf infestation and parasitism rate are influenced by the landscape diversity and that some plant species associated with alternative hosts of $D$. oleae parasitoids are related to a high rate of parasitism.

In addition to these findings, we would like to highlight the importance of the farmers' reports in assessing the current pest trends.

The collaboration between the farmers and scientists, contributes to the establishment of a sensitive landscape management. This approach may help preserve natural enemies, improves the reliability and effectiveness of the pest suppression service in order to prevent or reduce the severity of pest outbreaks.

Acknowledgements The authors would like to thank all the farmers involved and technicians of consortium OLMA, Terre dell'Etruria and Consorzio Agrario del Tirreno for help, efficiency, quick reports and information. We want to thank Alice Caselli and Simone Marini for her useful suggestions. We acknowledge anonymous reviewers for helpful suggestions.

Author contributions MSP and RP designed the survey. MSP, GM collect the leaves and inspected galls, NA made the vegetation samplings and landscape analysis. ET analysed data. MSP wrote the manuscript. All authors read and approved the manuscript.

Funding Open access funding provided by Scuola Superiore Sant'Anna within the CRUI-CARE Agreement. Open access funding provided by Scuola Superiore Sant'Anna within the CRUI-CARE Agreement. The study was supported by Regional Phytosanitary Service of Tuscany.

\section{Declarations}

Conflict of interest The authors have no relevant financial or non-financial interests to disclose.
Open Access This article is licensed under a Creative Commons Attribution 4.0 International License, which permits use, sharing, adaptation, distribution and reproduction in any medium or format, as long as you give appropriate credit to the original author(s) and the source, provide a link to the Creative Commons licence, and indicate if changes were made. The images or other third party material in this article are included in the article's Creative Commons licence, unless indicated otherwise in a credit line to the material. If material is not included in the article's Creative Commons licence and your intended use is not permitted by statutory regulation or exceeds the permitted use, you will need to obtain permission directly from the copyright holder. To view a copy of this licence, visit http://creativecommons.org/licenses/by/4.0/.

\section{References}

Aartsma, Y., Hao, Y., Dicke, M., van der Werf, W., Poelman, E. H., \& Bianchi, F. J. J. A. (2020). Variation in parasitoid attraction to herbivore-infested plants and alternative host plant cover mediate tritrophic interactions at the landscape scale. Landscape Ecology, 35, 907-919. https://doi.org/10.1007/s10980-020-00988-9

Albertini, A., Pizzolotto, R., \& Petacchi, R. (2017). Carabid patterns in olive orchards and woody semi-natural habitats: First implications for conservation biological control against Bactrocera oleae. BioControl, 62, 71-83. https://doi.org/10.1007/s10526-016-9780-x

Askew, R. R., Blasco-Zumeta, J., \& Pujade-Villar, J. (2001). Chalcidoidea and Mymarommatoidea (Hymenoptera) of a Juniperus thurifera L. forest of Los Monegros region, Zaragosa. Monografias Sociedad Entomológica Aragonesa, 4, 23.

Askew, R. R., Melika, G., Pujade-Villar, J., Schönrogge, K., Stone, G. N., \& Nieves-Aldrey, J. L. (2013). Catalogue of parasitoids and inquilines in cynipid oak galls in the West Palaearctic. Zootaxa, 3643, 1-133. https://doi.org/ 10.11646/zootaxa.3643.1.1

Barnes, H. F. (1948). Gall Midges of Economic Importance Vol. III: Gall midges of fruit, 184.

Barzman, M., Bàrberi, P., Birch, A. N. E., Boonekamp, P., Dachbrodt-Saaydeh, S., Graf, B., et al. (2015). Eight principles of integrated pest management. Agronomy for Sustainable Development, 35(4), 1199-1215. https:// doi.org/10.1007/s13593-015-0327-9

Batta, Y. A. (2019). New findings on infestation and phenology of Dasineura oleae Angelini (Diptera, Cecidomyiidae): An emerging pest on olive trees in the Palestinian Territories. Journal of Plant Diseases and Protection, 126(1), 55-66. https://doi.org/10.1007/ s41348-018-0196-y

Batta, Y., \& Doganlar, M. (2020). Olive leaf gall midge (Dasineura oleae Angelini, Diptera, Cecidomyiidae): Determination of olive tree infestation rates and quantification of parasitism by indigenous parasitoids. Journal of Plant Diseases and Protection, 127(1), 91-101. https://doi.org/10.1007/s41348-019-00270-4

Bengtsson, J., Ahnström, J., \& Weibull, A. C. (2005). The effects of organic agriculture on biodiversity and abundance: A meta-analysis. Journal of Applied Ecology, 
42(2), 261-269. https://doi.org/10.1111/j.1365-2664. 2005.01005.X

Bianchi, F. J. J. A., Booij, C. J. H., \& Tscharntke, T. (2006). Sustainable pest regulation in agricultural landscapes: A review on landscape composition, biodiversity and natural pest control. Proceedings of the Royal Society B: Biological Sciences, 273(1595), 1715-1727. https://doi. org/10.1098/rspb.2006.3530

Caselli, A., Francini, A., Minnocci, A., \& Petacchi, R. (2020). Dasineura oleae: Morphological and physiological characterization following the midge attack on olive leaves. Journal of Plant Disease and Protection. https:// doi.org/10.1007/s41348-020-00380-4

Chaianunporn, T., \& Hovestadt, T. (2015). Evolutionary responses to climate change in parasitic systems. Global Change Biology, 21(8), 2905-2916. https://doi.org/10. $1111 / \mathrm{gcb} .12944$

Chambers, J. M. (1992) Linear models. Chapter 4 of Statistical Models. In Seds J. M. Chambers and T. J. Hastie. Wadsworth \& Brooks/Cole

Chaplin-Kramer, R., \& Kremen, C. (2012). Pest control experiments show benefits of complexity at landscape and local scales. Ecological Applications, 22(7), 1936-1948. https://doi.org/10.1890/11-1844.1

Cronin, J. T., \& Reeve, J. D. (2005). Host-parasitoid spatial ecology: A plea for a landscape-level synthesis. Proceedings of the Royal Society b: Biological Sciences, 272(1578), 2225-2235. https://doi.org/10.1098/rspb.2005. 3286

Del Bene, G., \& Landi, S. (1993). Natural enemies of Dasineura gleditchiae (O.S.) (Diptera, Cecidomyiidae) in Italy. Redia, 76(1), 1-16.

Doğanlar, M. (2011). Parasitoids complex of the olive leaf gall midges, Dasineura oleae (Angelini 1831) and Lasioptera oleicola Skuhravá, 2011 (Diptera: Cecidomyiidae) in Hatay Turkey, with descriptions of new genus and species from Tetrastichinae (Hymenoptera: Eulophidae). Turkiye Entomoloji Dergisi, 35(2), 245-264.

Doğanlar, M., Sertkaya, E., \& Skuhravá, M. (2011). Pest status of olive leaf gall midge Dasineura oleae (Angelini, 1831), description of Lasioptera oleicola Skuhravá sp. new (Diptera: Cecidomyiidae) and effectiveness of parasitoids on their populations in Hatay Turkey. Turkiye Entomoloji Dergisi, 35(2), 265-284.

Frere, I., Fabry, J., \& Hance, T. (2007). Apparent competition or apparent mutualism? An analysis of the influence of rose bush strip management on aphid population in wheat field. Journal of Applied Entomology, 131(4), 275-283. https://doi.org/10.1111/j.1439-0418.2007.01157.x

Gallé, R., Happe, A. K., Baillod, A. B., Tscharntke, T., \& Batáry, P. (2019). Landscape configuration, organic management, and within-field position drive functional diversity of spiders and carabids. Journal of Applied Ecology, 56(1), 63-72. https://doi.org/10.1111/1365-2664.13257

Ghahari, H., \& Buhl, P. N. (2011). Check-list of Iranian Platygastridae (Hymenoptera, Platygastroidea). Entomofauna, 32(8), 329-336.

Gomez, J. F., Hernández Nieves, M., Garrido Torres, A. M., Askew, R. R., \& Nieves-Aldrey, J. L. (2006). Los Chalcidoidea (Hymenoptera) asociados con agallas de cinípidos
(Hymenoptera, Cynipidae) en la comunidad de Madrid. Graellsia (número Extraordinario), 62, 293-331.

Graham, M. W. (1969). The Pteromalidae of North- Western Europe (Hymenoptera: Chalcidoidae). Bulletin of the British Museum (Natural History). Entomology, Suppl. 16, 1-909.

Greenop, A., Woodcock, B. A., Wilby, A., Cook, S. M., \& Pywell, R. F. (2018). Functional diversity positively affects prey suppression by invertebrate predators: A meta-analysis. Ecology, 99(8), 1771-1782. https://doi.org/ 10.1002/ecy. 2378

Griffin, J. N., Byrnes, J. E. K., \& Cardinale, B. J. (2013). Effects of predator richness on prey suppression: A metaanalysis. Ecology, 94(10), 2180-2187. https://doi.org/10. 1890/13-0179.1

Haan, N. L., Zhang, Y., \& Landis, D. A. (2020). Predicting landscape configuration effects on agricultural pest suppression. Trends in Ecology and Evolution, 35(2), 175186. https://doi.org/10.1016/j.tree.2019.10.003

Happe, A. K., Alins, G., Blüthgen, N., Boreux, V., Bosch, J., García, D., et al. (2019). Predatory arthropods in apple orchards across Europe: Responses to agricultural management, adjacent habitat, landscape composition and country. Agriculture, Ecosystems and Environment, 273, 141-150. https://doi.org/10.1016/j.agee.2018.12.012

Hawro, V., Ceryngier, P., Tscharntke, T., Thies, C., Gagic, V., Bengtsson, J., et al. (2015). Landscape complexity is not a major trigger of species richness and food web structure of European cereal aphid parasitoids. BioControl, 60(4), 451-461. https://doi.org/10.1007/s10526-015-9660-9

Haynes, K. J., Allstadt, A. J., \& Klimetzek, D. (2014). Forest defoliator outbreaks under climate change: Effects on the frequency and severity of outbreaks of five pine insect pests. Global Change Biology, 20(6), 2004-2018. https:// doi.org/10.1111/gcb.12506

He, X. Z., \& Wang, Q. (2011). Phenological dynamics of Dasineura mali (Diptera: Cecidomyiidae) and its parasitoid Platygaster demades (Hymenoptera: Platygasteridae) in apple orchards. Journal of Economic Entomology, 104(5), 1640-1646. https://doi.org/10.1603/ec11090

Herting, B., \& Simmonds, F. J. (1973). A catalogue of parasites and predators of terrestrial arthropods. Section A. Host or Prey/Enemy: Coleoptera to Strepsiptera. Commonwealth Agricultural Bureaux, Farnham Royal.

Herting, B., \& Simmonds, F. J. (1975). A catalogue of parasites and predators of terrestrial arthropods. Section A. Host or Prey/Enemy: Lepidoptera, Part 1 (Microlepidoptera). Commonwealth Agricultural Bureaux, Farnham Royal.

Hothorn, T., Bretz, F., \& Westfall, P. (2008). Simultaneous inference in general parametric models. Biometrical Journal, 50(3), 346-363. https://doi.org/10.1002/bimj.20081 0425

ISMEA. (2018). La produzione italiana di olio di oliva. Stime della campagna produttiva 2017/18. www.ismeamercati.it

Kassambara, A., \& Mund, F. (2019). factoextra: extract and visualize the results of multivariate data analyses. $R$ packageversion 1.0.6.

Kruess, A., \& Tscharntke, T. (1994). Habitat fragmentation, species loss, and biological control. Science, 264(5165), 
1581-1584. https://doi.org/10.1126/science.264.5165. 1581

Kruess, A., \& Tscharntke, T. (2000). Species richness and parasitism in a fragmented landscape: Experiments and field studies with insects on Vicia sepium. Oecologia, 122(1), 129-137. https://doi.org/10.1007/PL00008829

Lê, S., Josse, J., \& Husson, F. (2008). FactoMineR: An R package for multivariate analysis. Journal of Statistical Software, 25(1), 1-18. https://doi.org/10.18637/jss.v025.i01

Lenth, R. (2020). emmeans: Estimated Marginal Means, aka Least-Squares Means. $R$ package version 1.4.5.

Letourneau, D. K., Jedlicka, J. A., Bothwell, S. G., \& Moreno, C. R. (2009). Effects of natural enemy biodiversity on the suppression of arthropod herbivores in terrestrial ecosystems. Annual Review of Ecology, Evolution, and Systematics, 40, 573-592. https://doi.org/10. 1146/annurev.ecolsys.110308.120320

Maselli, F., Chiesi, M., Brilli, L., \& Moriondo, M. (2012). Simulation of olive fruit yield in Tuscany through the integration of remote sensing and ground data. Ecological Modelling, 244, 1-12. https://doi.org/10.1016/j. ecolmodel.2012.06.028

McGarigal, K., Cushman, S., \& Ene, E. (2012). FRAGSTATS v4: Spatial Pattern Analysis Program for Categorical and Continuous Maps.

Meiners, T. (2015). Chemical ecology and evolution of plantinsect interactions: A multitrophic perspective. Current Opinion in Insect Science, 8, 22-28. https://doi.org/10. 1016/j.cois.2015.02.003

Moon, K.-W. (2018). ggiraphExtra: make interactive "ggplot2". extension to "ggplot2" and "ggiraph". $R$ package version 0.2.9.

Öncuier, C. (1991). A catalogue of the parasites and predators of insect pests of Turkey.

Peel, M. C., Grieser, J., Beck, C., Rudolf, B., \& Rubel, F. (2007). Updated world map of the Koppen-Geiger climate classification. Meteorologische Zeitschrift, 11, 1633-1644. https://doi.org/10.1127/0941-2948/2006/ 0130

Petacchi, R., Picchi, M. S., Tondini, E., Caselli, A., \& Monteforti, G. (2019). Lotta biologica conservativa alla cecidomia dell'olivo. Informatore Agrario, 44, 43-45.

Picchi, M. S., Bocci, G., Petacchi, R., \& Entling, M. H. (2016). Effects of local and landscape factors on spiders and olive fruit flies. Agriculture, Ecosystems \& Environment, 222, 138-147. https://doi.org/10.1016/j.agee. 2016.01.045

Picchi, M. S., Marchi, S., \& Petacchi, R. (2017). Cecidomia delle foglie dell'olivo: Nuovo rischio o vecchio problema ? Informatore Agrario, 16, 49-52.

Picchi, M. S., Bocci, G., Petacchi, R., \& Entling, M. H. (2019). Taxonomic and functional differentiation of spiders in habitats in traditional olive production landscapes in Italy. European Journal of Entomology, 117, 18-26. https://doi. org/10.14411/eje.2020.002

Power, M. E. (1992). Top-down and bottom-up forces in food webs: Do plants have primacy ? Ecology, 73(3), 733-746.

QGIS Development Team. (2019). QGIS Geographic Information System. Open Source Geospatial Foundation Project. http://qgis.osgeo.org.
R Development Core Team, R. (2016). R: a language and environment for statistical computing. In R. D. C. Team, Ed., $R$ Foundation for Statistical Computing. Vienna: $\mathrm{R}$ Foundation for Statistical Computing. https://doi.org/10. 1007/978-3-540-74686-7

Redlich, S., Martin, E. A., \& Steffan-Dewenter, I. (2018). Landscape-level crop diversity benefits biological pest control. Journal of Applied Ecology, 55, 2419-2428. https://doi.org/10.1111/1365-2664.13126

Regione Toscana. (2012). La Toscana aL $6^{\circ}$ censimento generale dell'agricoltura-Risultati definitivi.

Regione Toscana, S. I. T. ed A. (2020). Geoscopio WebGIS. https://www.regione.toscana.it/-/geoscopio

Ritchie, M. E., \& Olff, H. (1999). Spatial scaling laws yield a synthetic theory of biodiversity. Nature, 400(August), $2-5$.

Rosenheim, J. A. (1998). Higher-order predators and the regulation of insect. Annual Review of Entomology, 42, 421-447.

Revelle, W. (2020) psych: Procedures for Personality and Psychological Research, Northwestern University, Evanston, Illinois, USA, https://CRAN.R-project.org/package= psych. Version $=2.1 .3$.

Roubos, C. R., \& Liburd, O. E. (2013). Parasitism of Dasineura oxycoccana (Diptera: Cecidomyiidae) in North Central Florida. Environmental Entomology, 42(3), 424-429. https://doi.org/10.1603/EN12307

Sampson, B. J., Stringer, S. J., \& Spiers, J. M. (2002). Integrated Pest Management for Dasineura oxycoccana (Diptera: Cecidomyiidae) in blueberry. Environmental Entomology, 31(2), 339-347. https://doi.org/10.1603/ 0046-225x-31.2.339

Schweiger, O., Maelfait, J. P., Van Wingerden, W., Hendrickx, F., Billeter, R., Speelmans, M., et al. (2005). Quantifying the impact of environmental factors on arthropod communities in agricultural landscapes across organizational levels and spatial scales. Journal of Applied Ecology, 42(6), 1129-1139. https://doi.org/10.1111/j.1365-2664.2005. 01085.x

Skuhrava M., \& Skuravy V. (1994). Galls midge (Diptera: Cecidomyiidae) of Italy. Entomologica, Bari, 28:45-76. https://doi.org/10.15162/0425-1016/650

Silva, R., \& Clarke, A. R. (2020). The "sequential cues hypothesis": A conceptual model to explain host location and ranking by polyphagous herbivores. Insect Science, 27, 1136-1147. https://doi.org/10.1111/1744-7917.12719

Sofo, A., Manfreda, S., Dichio, B., Fiorentino, M., \& Xiloyannis, C. (2008). The olive tree: A paradigm for drought tolerance in Mediterranean climates. Hydrology and Earth System Sciences Discussions, 4(5), 2811-2835. https:// doi.org/10.5194/hessd-4-2811-2007

Steffan-Dewenter, I. (2002). Landscape context affects trapnesting bees, wasps, and their natural enemies. Ecological Entomology, 27(5), 631-637. https://doi.org/10.1046/j. 1365-2311.2002.00437.x

Thies, C., Roschewitz, I., \& Tscharntke, T. (2005). The landscape context of cereal aphid-parasitoid interactions. Proceedings of the Royal Society b: Biological Sciences, 272(1559), 203-210. https://doi.org/10.1098/rspb.2004. 2902 
Tondini, E., \& Petacchi, R. (2019). First observations on the parasitoid complex and on the biology of Dasineura oleae during an outbreak in Tuscany, Italy. Bulletin of Insectology, 72(1), 93-102.

Tscharntke, T., Klein, A. M., Kruess, A., Steffan-Dewenter, I., \& Thies, C. (2005). Landscape perspectives on agricultural intensification and biodiversity -Ecosystem service management. Ecology Letters, 8(8), 857-874. https://doi. org/10.1111/j.1461-0248.2005.00782.x

Tschumi, M., Albrecht, M., Bärtschi, C., Collatz, J., Entling, M. H., \& Jacot, K. (2016). Perennial, species-rich wildflower strips enhance pest control and crop yield. Agriculture, Ecosystems and Environment, 220, 97-103. https:// doi.org/10.1016/j.agee.2016.01.001

Vallebona, C., Pellegrino, E., Frumento, P., \& Bonari, E. (2015). Temporal trends in extreme rainfall intensity and erosivity in the Mediterranean region: A case study in southern Tuscany, Italy. Climatic Change, 128(1-2), 139151. https://doi.org/10.1007/s10584-014-1287-9

Veres, A., Petit, S., Conord, C., \& Lavigne, C. (2013). Does landscape composition affect pest abundance and their control by natural enemies? A review. Agriculture, Ecosystems and Environment, 166, 35-45. https://doi.org/10. 1016/j.agee.2011.05.027

Vidal, S. (1997). Determination list of entomophagous insects. Nr. 13. Bulletin. Section Regionale Ouest Palaearctique, Organisation Internationale de Lutte Biologique. 20(2), 22.

Viggiani, G. (1967). Studies on Hymenoptera Chalcidoidea. XI. Chalcidoidea of the Parco Gussone (1st note). Bollettino del Laboratorio di Entomologia Agraria "Filippo Silvestri", Portici, 25, 153.
Wackers, F. L. (2002). The effect of food supplements on parasitoid- host dynamics. $1^{\text {st }}$ International Symposium on Biological Control of Arthropods-Hunolulu, Hawai, USA (pp. 226-231).

With, K. K. A., Pavuk, D. M. D., Worchuck, J. J. L., Oates, R. K., \& Fisher, J. L. (2002). Threshold effects of landscape structure on biological control in agroecosystems. Ecological Applications, 12(1), 52-65. https://doi.org/10. 2307/3061136

Xiao, H., Sun, L., Jiao, T., \& Li, Z. (2016). A revision of Chinese species of Mesopolobus Westwood (Hymenoptera : Pteromalidae) with descriptions of four new species from China. Zoological Systematics, 41(1), 64-81. https://doi. org/10.11865/zs.201604

Zhang, Y., Moges, S., \& Block, P. (2016). Optimal cluster analysis for objective regionalization of seasonal precipitation in regions of high spatial-temporal variability: Application to Western Ethiopia. Journal of Climate, 29(10), 3697-3717. https://doi.org/10.1175/JCLI-D-15-0582.1

Zuur A., Ieno E. N., Walker N., Saveliev A. A., \& Smith G. M. (2009). Mixed effects models and extensions in ecology with R.574.

Publisher's note Springer Nature remains neutral with regard to jurisdictional claims in published maps and institutional affiliations. 